Journal of Nepal Agricultural Research Council

Vo.l 7: 133-150, April 2021

ISSN: 2392-4535 (Print), 2392-4543 (Online)

DOI: https://doi.org/10.3126/jnarc.v7i1.36937

A Review

\title{
Sustainable Intensification in Agriculture: An Approach for Making Agriculture Greener and Productive
}

Jiban Shrestha ${ }^{1}$, Subash Subedi ${ }^{2}$, Krishna Prasad Timsina ${ }^{3}$, Sudeep Subedi ${ }^{1}$, Meena Pandey ${ }^{4}$, Aakriti Shrestha ${ }^{5}$, Sajina Shrestha ${ }^{5}$ and Mohammad Anwar Hossain ${ }^{6}$

${ }^{1}$ Nepal Agricultural Research Council, National Plant Breeding and Genetic Research Centre, Khumaltar, Lalitpur, Nepal: @: jibshrestha@ gmail.com; ORCID: https://orcid.org/0000-0002-3755-8812

${ }^{2}$ Hill Crops Research Program, Kabre, Dolakha, Nepal: subedi.subash1@gmail.com; ORCID: https://orcid.org/0000-0003-3739-1773

${ }^{3}$ National Agricultural Policy Research Centre, Khumaltar, Lalitpur Nepal: krishnatimsina2000@ gmail.com; ORCID: https://orcid.org/0000-0003-4005-7039

${ }^{1}$ National Plant Breeding and Genetic Research Centre, Khumaltar, Lalitpur Nepal: sudeepsubedi111a@gmail.com; ORCID: https://orcid.org/0000-0002-4478-704X

${ }^{4}$ Paklihawa Campus, Institute of Agriculture and Animal Science, TU, Rupandehi, Lumbini, Nepal: pandeymeena999@gmail.com; ORCID: https://orcid.org/0000-0003-3556-6656

${ }^{5}$ Himalayan College of Agricultural Science and Technology, Purbanchal University, Kathmandu, Nepal: aakiritistha2016@gmail.com; ORCID: https://orcid.org/0000-0002-4906-9231

${ }^{5}$ Himalayan College of Agricultural Science and Technology, Purbanchal University, Kathmandu, Nepal: sajina.shrestha07@gmail.com; ORCID: https://orcid.org/0000-0002-5710-6135

${ }^{6}$ Deptartment of Genetics and Plant Breeding, Bangladesh Agricultural University, Mymensingh-2202,

Bangladesh: anwargpb@bau.edu.bd; ORCID: https://orcid.org/0000-0001-9415-012X

Received 11 August, 2020, Revised 13 March, 2021, Accepted 10 April, 2021, Published 30 April, 2021

Scientific Editors: Amit Prasad Timsina and Sabir Hussain Shah

Copyright $(0) 2021$ NARC. Permits unrestricted use, distribution and reproduction in any medium provided the original work is properly cited.

The authors declare that there is no conflict of interest.

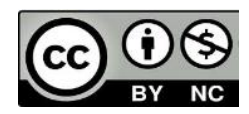

OPEN

Licensed under the Creative Commons Attribution NonCommercial 4.0 International (CC BY-NC 4.0)

\section{ABSTRACT}

Sustainable intensification of agriculture is a good approach for reducing the yield gap without exacerbating the current condition of the environmental components, which is a big challenge for agriculture in the modern world. This review provides a summary of the role and approaches of sustainable intensification in agriculture which offer ways to increase crop production and create long-term sustainability in agriculture production. The current demand for food has continued to rise as a result of the world's rapidly increasing population. In order to increase crop/food production, agricultural systems should be intensified by more sustainable practices, as well as by reforming existing production systems/techniques and diversifying them into newer and more profitable enterprises. Despite the heavy use of inputs, farmers have recently been unable to achieve optimal crop yields. The judicious use of agricultural inputs, combined with improved management techniques, is important for advancing sustainable intensification. New scientific techniques in agronomic practices, as well as improved farm mechanization, are helping to boost resource use efficiency in sustainable crop production. The sustainable agricultural intensification is necessary to increase the agricultural productivity under the changing and adverse climatic conditions while maintaining healthy production practices.

Keywords: Agriculture, food security, intensification, sustainability

\section{सारांश}

आधुनिक विश्वको प्रमुख चुनौतिको रूपमा रहेको वर्तमान जलवायु परिवर्तनको अवस्थालाई थप हानी नपुर्याई उत्पादनमा रहेको अन्तरलाई कम गर्नका लािि कृषिको दिगो सघनता एक उपयोगी विधि हो । यस लेखमा कृषि उत्पादनमा दिगो कृषि सघनताको भिमिकाबारे सार र खाद्य सुरक्षा प्राप्तिको बारेमा समीक्षा गरिएको छ। दिगो कृषि सघनता प्राप्तिको लक्ष्यमा सहयोग पुचाउने विभिन्न पद्धतिबारे पनि यहाँ उजागर गरिएको छ। विश्वको दुत गतिमा बढिरहेको जनसंख्याको परिणाम स्वरूप हाल खाद्यान्नको माग लगातार बढ़रहेको छ। हालको कृषि उत्पादनलाई वृद्धि गर्न कृषि प्रणालीलाई थप सुधार गर्ने, बाली विविधीकरण गरी नयाँ उत्पादनमूलक उद्यमशिलताको विकाश गर्ने र थप दिगो अभ्यासहरूको प्रयोग गर्नुपर्ने छ। दिगो कृषि विकासका माध्यमबाट खाद्य र 
पोषण सुरक्षालाई प्रोत्साहन गरिन्छ। कृषिमा प्रयोग हुने बिभिन्न सामग्रीहरूको समूचित प्रयोग साथै सुधारिएको व्यवस्थापनका तरिकाहरू दिगो सघनीकरणको लागि महत्वपर्ण हुन्छ। बाली विकाशका नवीनतम बैज्ञानिक तरिकाहरू तथा सुधारिएको कृषि यान्त्रिकीकरणले श्रोत उपयोग दक्ष्यताको वृद्धि लाई सहयोग गर्दछ। कृषिमा प्रयोग हुने सामग्रीको भारी प्रयोगको बावजुद किसानहरूले अधिकतम बाली उत्पादन प्राप्त गर्न सकिरहेका छैनन्। अहिलेको बदलिदो वातावरणिय अवस्थामा सुरक्षित उत्पादनका अभ्यासहरुको प्रयोग गरेर कृषि उत्पादनलाई वृद्धि गर्न कृषिको दिगो सघनताको आवश्यकता छ।

\section{INTRODUCTION}

Agricultural intensification is a technique for increasing per-hectare yields rather than expanding the area of land under cultivation by making better use of inputs (Angelsen and Kaimowitz 2001). Since arable land is limited and will be reduced in the near future, most of the additional production will have to come from sustainable agricultural intensification (FAO 2019). The major ways to increase the productivity of land sustainably are by increasing crop yields above the baseline and applying double-cropping practice (Filho et al 2018). Double cropping increasingly allows farmers to increase the harvested area on shrinking agricultural areas (Szabo 2015). The environmental costs of intensification have received increasing attention over the last decade. The negative impacts of fertilizers, pesticides, and the huge amounts of water needed for irrigation, are well advertised. This has led to calls for 'sustainable intensification' (Evans 2019). Sustainable intensification (SI) is described as an agricultural process or system that maintains or improves valued outcomes while maintaining or improving environmental outcomes (Pretty et al 2018). It is a strategy for increasing productivity on existing agricultural land with positive environmental and social impacts (Donovan 2020). Both the terms "sustainable" and "intensification" are equally essential (Donovan 2020). Sustainable intensification has recently received a lot of attention as a way to deal with the problem of feeding a growing population in a world with limited resources (Cook et al 2015). It is a method or system for increasing yields while reducing environmental impact and allowing for the cultivation of more land (The Royal Society 2009). Sustainable intensification is responsible for increasing biomass availability without harming the environment, which is needed for increased bio-energy, food, feed, and fiber production. Food security and sustainable agriculture are inextricably related. Sustainable agricultural practices tend to make a significant contribution to food security by increasing food supply and nutrient quality (Paciello 2015). Agriculture becomes greener and productive as a result of sustainable intensification. The word "green" refers to products that are environmentally friendly and long-lasting, i.e., have a low negative effect on the environment and ecosystems (Struik and Kuyper 2017). Importantly, sustainable intensification lowers the ecosystem's greenhouse gas emissions. One reason for limited agricultural intensification is that land pressure and market demand may not be inducing farmers to intensify how they produce their crops (Nin-Pratt and McBride 2014). However, in areas with significant land pressure and good access to agricultural markets, the concern is that farmers are not able to access the inputs and infrastructure necessary to intensify their crop production (Diao and Silver 2016).

Factors that limit the sustainability of agricultural development are related to any community's access to education, infrastructure, and health care. Farmers will be unable to enter markets in order to obtain fertilizer and seeds, as well as sell their produce. Labor shortages, restricted access to farm credit, and poor governance are all barriers to sustainable agriculture development (Sumberg 2005, Pretty et al 2011). The adoption of sustainable agricultural development in a country has encountered many obstacles. These include: (i) agricultural water-use shortage; (ii) cultivated land loss; and (iii) inappropriate usage of fertilizers and pesticides, and environmental degradation (Zhao et al 2008). The other prominent challenges include population growth, inadequate support services, framework and institutional constraints, and lack of agricultural and rural development policies (Shalaby et al 2011). In this review article we give an overview on the impacts of sustainable intensification on crop productivity and explore the possible approaches of sustainable intensification in agriculture. We also critically discuss the ways to intensify crop production and create sustainability in agricultural production.

\section{Agricultural Intensification}

Agriculture intensification refers to the transformation of crop and non-crop vegetation as well as farm management activities. Reduced crop species and varieties, as well as trees, trap crops, and 
weeds, are among the changes in vegetation. Other local management improvements include increased chemical pesticide and fertilizer application, increased tillage and irrigation, and heavier mechanization (Philpott 2013). Agricultural intensification can be technically defined as an increase in agricultural production per unit of inputs (labour, land, time, fertilizer, seed, feed or cash). It has been defined in three ways: (i) increasing crop productivity; (ii) improving cropping intensity (i.e., two or more crops) per unit of land or livestock intensity (e.g., faster maturing breeds); and (iii) changing land use such that we can harvest crops with high market or nutritional value. Agricultural intensification has resulted in a significant increase in soil nutrient demand from crop production; however, meeting this demand with synthetic fertilizers comes at a high cost in terms of energy, the climate, and public health (Jones et al 2013). Intensification of agricultural production includes the adoption of sustainable yield increasing technologies, fertilizer use, supplementary irrigation and/or water conservation, high yielding cultivars and improved crop management practices (Pandey et al 2002). The different types of inputs required for agricultural intensification are given in Table 1.

Table 1. An overview of various types of inputs to agricultural intensification

\begin{tabular}{ll}
\hline $\begin{array}{l}\text { Direct inputs: } \\
\text { Use of which imply to } \\
\text { influence the outputs } \\
\text { from the farm directly }\end{array}$ & $\begin{array}{l}\text { Labour, in form of either human or mechanized } \\
\text { Water, either through rainfall or application of irrigation } \\
\text { Inorganic chemicals and/or organic matter, such as fertilizers, Farm Yard Manure } \\
\text { (FYM), crop residue and pesticides } \\
\text { Biodiversity, be it new crop varieties or livestock breed }\end{array}$ \\
\hline $\begin{array}{l}\text { Indirect inputs: } \\
\text { Use of which is often } \\
\text { responsible to alter or } \\
\text { modify the use of direct } \\
\text { inputs }\end{array}$ & $\begin{array}{l}\text { Fnancial capital, for investment in inputs and other changes to the farming system } \\
\text { Infrastructure, to allow reach to input and output markets } \\
\text { Technology, which generates and supports new forms and ways of using direct inputs } \\
\text { Markets, as an outlet for increased outputs. }\end{array}$ \\
\hline
\end{tabular}

Source: Panel 2013

The sources of outputs of agricultural intensification are given in Table 2.

Table 2. Definitions and sources of three outputs of agricultural intensification

\begin{tabular}{|c|c|c|c|}
\hline & Production & Income & Nutrition \\
\hline Definition & $\begin{array}{l}\text { Total yields of food per unit } \\
\text { area }\end{array}$ & $\begin{array}{l}\text { Amount of net earnings generated } \\
\text { per unit input }\end{array}$ & $\begin{array}{l}\text { Human consumption of } \\
\text { nutrients per unit input }\end{array}$ \\
\hline $\begin{array}{l}\text { Resulting } \\
\text { from: }\end{array}$ & $\begin{array}{l}\text { Improved high yielding, crop } \\
\text { varieties or livestock breeds } \\
\text { which are resistant to drought, } \\
\text { pest and disease } \\
\text { Better crop cultivation and } \\
\text { management or livestock breeds } \\
\text { High efficacious inputs of } \\
\text { water, nutrients or remedy for } \\
\text { control of pests, diseases and } \\
\text { weeds } \\
\text { Make full use of synergies } \\
\text { between crops and livestock }\end{array}$ & $\begin{array}{l}\text { Approach to fair and efficient output } \\
\text { markets } \\
\text { Transparent and high market and } \\
\text { price information } \\
\text { Upgrade from low value to high- } \\
\text { value crops or livestock } \\
\text { Diversification of income-generating } \\
\text { activities, including: } \\
\text { Adjustment of the farm or household } \\
\text { enterprise } \\
\text { Exploiting new market opportunities } \\
\text { Increasing off farm income }\end{array}$ & $\begin{array}{l}\text { New varieties of staple } \\
\text { crops or breeds of } \\
\text { livestock with } \\
\text { improved nutritive } \\
\text { value } \\
\text { Diversification of } \\
\text { production towards } \\
\text { higher overall nutritive } \\
\text { value }\end{array}$ \\
\hline
\end{tabular}

Source: Panel 2013

Intensification of agriculture helps to improve the livelihoods of farmers and improve their economic and social conditions through increased food security and employment. It is proved to be a viable option for a better livelihood in the context of Nepal. Intensification of agriculture has led to an improved economy, food security, employment, decision-making, division of tasks, local institutions and leadership (Raut et al 2010). Traditional farming methods cannot meet the growing demand for food and there are few opportunities to expand agricultural land, production per hectare must be increased. The intensification of agriculture will therefore be crucial to meet the growing demand for food and to increase the standard of living of farmers. The global drivers of intensification are population, income opportunities, access to roads and markets, agricultural inputs and support from 
external organizations (Dahal et al 2008). Agricultural intensification involves intensive farming which makes the use of various kinds of chemical fertilizers, pesticides, and insecticides. Intensified agriculture come-up with heavy use of nitrogen fertilizers, may lead to increased soil acidification, resulting in decreased soil quality. Micronutrients removed in the bumper harvests are usually not replaced by standard N-P-K fertilizers, so micronutrients deficiencies may appear, decreasing the soil quality (Rahat 2015). Increased application of pesticides and fertilizers has a detrimental effect on the wider environment with bodies of water situated close to intensive farms. The application of these chemicals has negative impacts on environment and biodiversity. The contaminated farm products are more hazardous to human and animal health.

\section{Sustainable Agriculture}

Sustainable agriculture refers to the practice of production of field crops, vegetables, livestock, and fisheries using farming techniques that protect the environment, public health, human communities, and animal welfare. It integrates three main goals: (i) environmental health; (ii) economic profitability; and (iii) social and economic equity (Denton 2020) (Figure 1). Sustainable production systems should exhibit several key attributes at the production end of food systems (Pretty 2008, The Royal Society 2009).

The concept of sustainability in the scenario of food and agricultural production is the chief factor to any future challenges (Pretty 2008). It follows the following four underlying principles:

1. Persistence: it refers to the ability to carry on the desirable outputs over a long period, therefore confers predictability.

2. Resilience: it refers to the ability to absorb, use or even take benefit from the harsh condition and to exist without any qualitative and contextual modification or changes in structure.

3. Autarchy: it means the ability to provide desirable outputs from factors of production (inputs and resources) obtained from within key system boundaries.

4. Benevolence: it centers around the concept of the ability to generate desirable outputs (food, fibre, fuel, oil) with due consideration to sustain the function of ecological service and not degrading natural capital (eg, biodiversity, minerals, soil, clean water etc.).

The sustainable agriculture limits the proper use of land. Besides, it also hinders the full exploitation of land, labor and capital. The disadvantages of sustainable agriculture are lowered income, bigger consumption of time and effort, and shorter shelf life of products (Farming Base 2021).

\section{Approaches of sustainable agriculture}

Sustainable agriculture is a broad term that encompasses a variety of approaches. Planting climateresilient and high-yielding crop varieties, intercropping legumes in cereals, biodiversification, participatory breeding, conservation agriculture, and Integrated Pest Management are all examples of sustainable intensification (Shrestha 2016). There are several approaches used to ensure sustainable agriculture.

\section{Crop rotation}

Crop rotation is a method of growing various crops in a specific order on the same piece of land in order to preserve soil fertility and productivity over time (Folnovic 2021). It aims to maximize resource efficiency and sustain soil fertility levels that are beneficial to plants, allowing for higher and higher-quality production with minimal environmental impact. Crop rotation disrupts insect and pathogen reproduction and hence their life cycle. Plant nutrients are restored when certain plant species are included in crop rotation, requiring less chemical fertilizer. Crop rotation is a useful technique in the practice of sustainable agriculture. Rotation necessitates more time for field preparation prior to rotation. Fungi and pests from a previous crop can cause problems with the new crop. Some crops are better at coexisting with weeds and fungi than others, and growing new crops can be challenging. When a new crop is planted, plant residues can also cause diseases. 


\section{Polyculture farming}

Polyculture is a method for growing two or more crops at the same time and in the same place (Adamczewska-Sowiska and Sowiski 2020). As a result, a polyculture crop production method entails the cultivation of several crops at the same time or in a crop rotation (Folnovic 2021). Polyculture is an integral part of sustainable agriculture because it allows better use of both crop space and labor resources than monoculture (Baldy and Stigter 1997). It allows efficient use of natural resources and produces a consistent yield under a variety of environmental conditions. In the cropping method, intercropping with legumes is beneficial. Rice-legume-vegetable, leguminous vegetable-wheatvegetable (cucumber), and rice-vegetable-legume are some examples of legume-based cropping patterns suggested by Regmi (1987). Farmers find it difficult to monitor and supervise ongoing farm operations when more than one form of plant is grown on a farm in a polyculture system. Farmers are becoming more knowledgeable about their crops as they cultivate a variety of crops. Planning and establishing a polyculture sector can be a time-consuming process. Polyculture cultivation can necessitate a higher initial investment in specialized equipment to meet the requirements of each plant species. A larger infrastructure is needed for polyculture. Polycultures will help us diversify our agricultural systems.

\section{Permaculture}

Permaculture is an approach and concept coined by David Holmgren and Bill Mollison in Australia in the 1970s (Lampeter Permaculture Group 2006). It is the harmonious integration of people and landscape providing foods, feeds, fibres, shelter, energy and other material and non-material needs in a sustainable way (Mollison 1988). The practices of permaculture consist of: (i) harvesting or rainwater, (ii) composting, (iii) use of pollinators (flowers, insect houses), nitrogen-fixers (clover), birds and bats (water features, food, habitat), etc. iv) replacing lawns and grass with productive crops, growing perennial food plants, (v) practice of no tilling, no chemical and synthetic fertilizers or pesticides, mulching, cover crops, and (vi) practicing agroforestry. Permaculture's unique problems can be related to concerns about its economic viability. This is a well-known strategy that could only be considered effective on a smaller, more self-sufficient scale. Permaculture can help farmers increase their yields and productivity.

\section{Biodynamic farming}

Dr. Rudolf Steiner, a scientist and philosopher, developed biodynamic agriculture in the early twentieth century as a method of sustainable agriculture (Biodynamic Association 2021). Biodynamic plants are those that are grown in the field in living soil, where they receive the nutrients that chemical fertilizers and hydroponic farming do not offer. Biodynamic farming encourages the use of poultry, composting, crop rotation, and cover cropping to preserve their own fertility. Centered on the theory of "anthroposophy," biodynamic farming combines holistic and ecological growing methods. Composting, using livestock manure from farmed animals, and cover cropping are all examples of sustainable agricultural practices. Biodynamic agriculture's unique strengths (Van Doorn et al 2016) may be construed as its unique challenges, in that it has a strong spiritual component, caters to a niche market, and necessitates its own training and quality label. Biodynamic farming necessitates more labor than conventional farming practices, increasing the cost of the produce. It is also not very conducive to mechanization, so it is difficult to practice on a large scale.

\section{Integrated Pest Management (IPM) and Bio intensive IPM}

Integrated Pest Management is a method of pest control that uses a combination of biological, cultural, mechanical, physical, and chemical tools to reduce economic, health, and environmental risks (Romeh 2018). Following pest detection, IPM recommends using biocontrol agents in the early stages and chemical agents as a last resort. IPM is an essential part of the long-term sustainability strategy. In an effort to increase the sustainability of an agricultural system, IPM "programs" are formulated on a combination of cultural, biological, mechanical, and chemical control methods (UC Sustainable Agriculture Research and Education Program 2017). Jha (2008) found that IPM-FFS (integrated pest management-farmers' field school) trained farmers used 36\% lesser amount (1.82 $\mathrm{kg} / \mathrm{ha})$ of active ingredients of pesticides than the non-trained farmers $(2.85 \mathrm{~kg} / \mathrm{ha})$. Similarly, another report GC (2011) stated that the pesticide application reduced up to 40\% in FFS implemented areas as 
compared with non-FFS areas. Application of IPM takes time. Much time is needed in planning itself. Individual farmers should have knowledge on the various control methods available.

The term "biointensive IPM" refers to a "systems approach to pest management focused on a knowledge of pest ecology." It starts with measures to effectively identify the existence and source of pest problems, then employs a variety of preventive strategies and biological controls to keep pest populations under control (Reddy 2012). Reduced chemical input costs, reduced on-farm and off-farm environmental effects, and more efficient and sustainable pest control are some of the advantages of introducing biointensive IPM (Dufour 2001). Some considerations for design improvements in the agricultural system; choice of pest-resistant cultivars; technical knowledge needs; control choices, record keeping, and equipment should be taken into account when designing a biointensive IPM program (Dufours 2001).

\section{Integrated Nutrient Management}

Integrated nutrient management (INM) is the process of optimizing the benefits from all possible sources of organic (farm yard manures, poultry manures, crop residues, green manures), inorganic (biofertilizers, etc.) and biological (biofertilizers, etc.) components in an integrated manner to maintain soil fertility and plant nutrient supply at an optimal level for maintaining the desired productivity. INM practice may be a cutting-edge and environmentally friendly approach for global agriculture sustainability ( $\mathrm{Wu}$ and $\mathrm{Ma}$ 2015). Integrated Nutrient Management is the process of maintaining optimal soil fertility and plant nutrient supply in order to maintain desired productivity. The aim of INM is to integrate the use of natural and man-made soil nutrients to increase crop productivity and preserve soil productivity for future generations (FAO 1995). The advantages of IPN as suggested by Naik (2017) are: (i) enhance the availability of applied as well as native soil nutrient, (ii). synchronizes the nutrient demand with the native supply from native and applied sources, (iii). provide balanced nutrition to the crops,(iv) improves and sustain the physical, chemical and biological functioning of soil,(v) minimizes the deterioration of soil, water and ecosystem by promoting carbon sequestration (vi) reducing nutrient losses to ground surface water bodies and atmosphere and (vii) minimize the antagonistic effects resulting from hidden deficiency and nutrient imbalance.

Chapagain and Gurung (2010) reported that maize yields under Improved and Farmers' management systems were found to be very similar to the research station yield, and were higher than the average productivity in the average farmers' field. Average maize yield using the Local cultivar under Farmers' management was $3.5 \mathrm{t} / \mathrm{ha}$ which was nearly 2.3 tons lower than the yield obtained with IPNS management and Improved cultivar. Efficient use of all nutrient sources, including organic sources, recyclable wastes, mineral fertilizers and bio-fertilizers should therefore be promoted through INM (Roy et al 2006).The degradation and over-exploitation of land is a big constraint to INM. For adoption of INM, farmers should have knowledge on use of fertilizers in balanced proportion. They have to purchase manure, fertilizers that are important for INM. Because of growing population, land is fragmented and farmer's holdings lands are becoming smaller. This prevents the application of INM at commercial level.

\section{Cover crops}

Cover crops are crucial to sustainable agricultural systems (Lu et al 2000). Through their rooting, these crops aid biological soil tillage; the surface mulch provides food, nutrients, and energy to earthworms, arthropods, and microorganisms that biologically till soils below ground. Under zerotillage regimes, deep-rooted cover crops and biological agents (earthworms) can also help alleviate compaction (Hobbs et al 2008). Cover crops can be thought of as a long-term investment in better soil quality and farm management (Clark 2015). They help to reduce soil erosion by increasing surface residue. They boost the soil's structure and water-holding capability, increasing the effectiveness of nitrogen fertilizer application ( $\mathrm{Lu}$ et al 2000). In crop rotations, cover crops can suppress weeds, provide shelter for beneficial predator insects, and serve as non-host crops for nematodes and other pests. Legume cover crops such as hairy vetch and crimson clover fix nitrogen and contribute to the nitrogen requirements of subsequent crops. Plants like clover or oat can check soil erosion, maintain soil fertility, suppress weed growth and improve the quality of soil. Cover crops add nutrients to the 
soil and minimize the need for chemical fertilizer in the soil. These crops enhance biodiversity on the farm and contribute to a healthier ecosystem. Cover crops may be difficult to include with tillage. These crops increase insect pests and disease. And, sometimes, they may foster allelopathic consequences - harmful effects from the release of biochemicals onto successive crops.

\section{Agroforestry}

Agroforestry is a land use management system that combines agricultural and forestry technologies to establish more complex, profitable, and long-term land use systems. It's an old technique used by farmers all over the world (Nair 1993). In Nepal's hilly areas, the agroforestry method is widely used. It integrates fast growing, $\mathrm{N}$-fixing woody species into small scale farming systems show great promise in enhancing by supplying and cycling of plant nutrients in soil-plant system. It also increases plant productivity and soil quality. Agroforestry is a holistic approach that has always played a critical role in Nepal's agricultural system's sustainability (Carson 1992, Yadav 1992). Agricultural production will also improve as forestry improves soil fertility and reduces soil erosion (Kang and Akinnifesi 2000). Likewise, agroforestry will increase food, feed and fuel wood (Young 1997). Agroforestry system is an ecologically rational and economically sound approach and is of great importance for the farmers in dry regions with soil prone to soil erosion causing desertification. Agricultural intensification is associated with loss of biodiversity; agroforestry is increasingly defined as an integrated land use that can directly increase plant diversity and also reduce habitat loss and fragmentation (Noble and Dirzo 1997). The biggest disadvantage of agroforestry is the huge amount of time required to reap the yields. There may be damage to food crops during tree harvesting operations. The tree may serve as hosts to insect pests that are harmful to food crops.

\section{Natural pest predators}

The predators, parasitoids, pathogens, and competitors are examples of natural enemies of insect pests, also known as biological control agents. Predation, parasitism, herbivory, and other natural processes are used in this approach, but it usually includes active human management. Biological pest control has long been regarded as one of the most promising innovations for long-term agricultural sustainability: it reduces reliance on conventional pesticides, reduces negative environmental effects, and increases worker protection while preserving crop production's economic viability (Tracy 2015).This approach is an economical, reliable and environmentally friendly pest management method; it uses living organisms to reduce pest populations. At the same time, the adverse effect on the environment is minimized by reducing the dependence on synthetic pesticides. Natural predators are those that live in agricultural fields (environment) and are involved in hunting of pests such as aphids, pollen beetles and slugs. This approach takes the farm as an ecosystem rather than a production factor whereby effective control over pests is found by natural predation of other creatures such as birds, animals etc. The biological control is unpredictable. Its unpredictability lies mostly in the fact that the natural enemies are dependent on the environmental conditions. Biological control method is slow process to achieve the pest control.

\section{Conservation agriculture (CA)}

Conservation agriculture was developed in the 1970s in Brazil and Argentina (Project Drawdown 2021). CA is based on three key principles: minimizing soil disturbance, preserving soil cover, and crop rotation management (FAO 2014). Conservation agriculture is a set of practices which is gaining popularity and focuses on minimum soil disturbance that aims to increase production and promote profitability by reviving soil fertility status. Conservation agriculture is a system approach which is characterized by three interlinked principles namely minimum soil disturbance, permanent soil cover and crop rotation (FAO 2010). Conservation agriculture is an agro-ecological approach to agricultural intensification that focuses on the implementation of three interconnected concepts based on locally formulated practices: minimal soil disturbance, permanent soil cover, and crop rotations (Dang 2019, Shrestha et al 2020). Conservation agriculture is a more sustainable and environmentally friendly management system for cultivating crops. It contributes to environmental conservation and to sustainable agricultural production by maintaining a permanent or semi-permanent organic soil cover. Conservation agriculture is a farming system designed to enhance the sustainability of agricultural production by conserving and protecting soil and water (Page et al 2020). 
Conservation agriculture, as a model for long-term production intensification, has a range of advantages for farmers, society, and the climate (Kassam et al 2010). CA strategies can have a significant positive impact on the environment, finances, social issues, and health (Sitholea et al 2016). The key practices under CA are minimizing soil disturbance, which entails reduced or notillage (through direct seed and/or fertilizer placement), maintaining soil cover by growing cover crops, leaving crop residues on land post-harvest and mulching, managing crop rotation, incorporating a wider range of plant species. Specific challenges relating to the implementation of CA are its dependence on herbicides, primarily to avoid soil disturbance when preparing to sow, and the consequent reliance on herbicide-resistant crops (Eslami 2014, Lee and Thierfelder 2017) and specific machinery adapted for direct seeding. These techniques reduce the higher levels of labour. The weight of the machinery used to plough the soil under in CA has been argued as one of the main contributors to soil compaction in the first place. Conservation agriculture could, in fact, lead to adverse impacts on the environment through its over-reliance on herbicides and genetically modified herbicideresistant crops (Eslami 2014). From an economic standpoint, in some cases the implementation of the approach may result in the demand for labour to increase, however the costs for certain machinery, fuel and fertilizer will at the same time decrease. Ghosh et al (2015) reported 79\% higher grain yield of wheat $(1700 \mathrm{~kg} / \mathrm{ha})$ in CA than conventional $(950 \mathrm{~kg} / \mathrm{ha})$. Bashour et al (2016) reported the production of wheat and yield was found to be more by $27 \%$ and $27.7 \%$ under the experimental plots of CA than conventional. Conservation agriculture aims to produce crop yields by reducing production costs, maintaining the soil fertility and conserving water (Hossain et al 2015). The yield gap was varied from 20 to $120 \%$ for CA in comparison with conventional tillage systems (Kassam et al 2009).

Conservation agriculture has come up as a new paradigm to achieve the goal of sustainable agricultural production. It is a major step towards the transition to sustainable agriculture. Conservation Agriculture requires a major change in mindset of farmers. In general, farmers should be more careful about the timing of agricultural operations. Particular attention should be paid to weed control through manual weeding or the rational use of herbicides. The $\mathrm{CA}$ requires a high initial cost of special planting machines.

\section{1) Organic farming}

The origins of organic agriculture can be traced all the way back to 1840, when mineral plant nutrition theory was established. The modern organic movement, on the other hand, arose concurrently with industrialized agriculture (OrganicNet 2016), with pioneers seeking alternative solutions to soil degradation, poor food quality, and low yields. Organic farming is an efficient and promising agricultural approach to sustainability as it ensures yield stability, improves soil health, does not cause environmental problems, and reduces the use of pesticides and synthetic fertilizers. Organic agriculture provides benefits in terms of environmental protection, conservation of nonrenewable resources, improved food quality, improve health status and the reorientation of agriculture towards areas of market demand (Parajuli et al 2020). Organic farming avoids the use of unhealthy traditional agricultural methods including synthetic fertilizers and pesticides. It preserves, protects, and enhances the ecosystem's quality. As a result, it is eventually linked to long-term growth (Vedantu 2021). According to the European Commission (EC) (2021), the principles of organic farming are: (i) The responsible use of energy and natural resources, (ii) The maintenance of biodiversity, (iii) Preservation of regional ecological balances, (iv) Enhancement of soil fertility, and (v) Maintenance of water quality. Organic farming also encourages a high standard of animal welfare and requires farmers to meet the specific behavioral needs of animals. Specific challenges relating to organic farming are often linked to evaluating its feasibility, often because many changes may only be observable in the long term. The practices of organic farming (European Parliament and Council 2018) are: (i) Prohibition of the use of GMOs, (ii) Forbidding the use of ionizing radiation, (iii) Limiting the use of artificial fertilizers, herbicides and pesticides to the minimum, and (iv) Prohibiting the use of hormones and restricting the use of antibiotics (only when strictly necessary) for animal health. In terms of sustainability, organic farming seeks to minimize the use of synthetic and chemical inputs. Production costs are higher for organic farming. Marketing and distribution of organic produce is not efficient because organic food is produced in smaller amounts. 
The benefits of sustainable agriculture underlie minimization of cost of inputs, maintain and conserve biodiversity; checks air pollution and soil erosion and speak for better treatment of animals. The drawbacks of sustainable agriculture are limited use of land without optimum use, reduced income, time consuming, more effort requirement and short shorter shelf life of products. The main disadvantage of sustainable agriculture is the limited land use, which makes it difficult to produce large quantities of food. As the land is used sparingly, the income from agriculture is very limited. Since the use of chemicals and fertilizers is minimal, it is very difficult to increase the fertility of the soil without using fertilizers and other chemicals. Successfully cultivating plants with minimal or no use of machinery takes longer and more people, which slows production (Farming Base 2021).

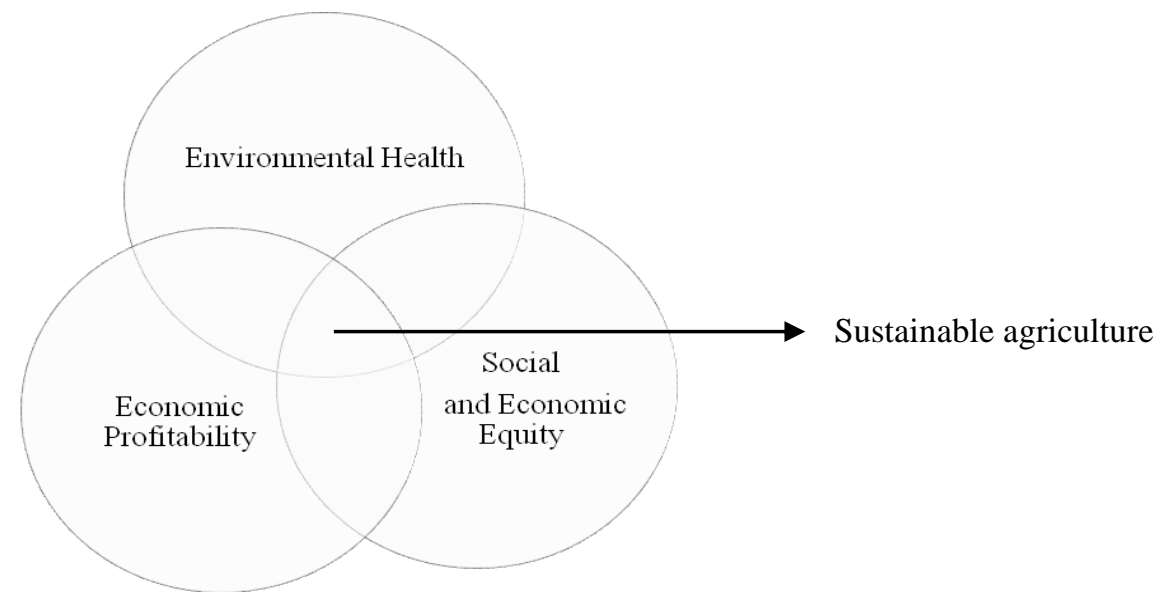

Figure 1. The three objectives of sustainable agriculture (Denton 2020)

\section{Sustainable Vs. Conventional Agriculture}

Sustainable agriculture seeks to grow a variety of crops without synthetic fertilizers or pesticides, while also improving soil composition and maintaining biodiversity. It's a more permanent form of agriculture that relies on ecosystem services to keep the environment intact while ensuring a sufficient harvest. Conventional agriculture often uses synthetic pesticides and fertilizers to maximize the yield of a particular genetically modified crop or group of crops. This method requires significant quantity of chemicals and energy input and weakens the landscape ecology. The difference between sustainable and conventional agriculture is given in Table 3.

Conventional agriculture generally does not use sustainable practices such as ground cover and natural fertilizers such as manure. This farming uses chemical fertilizers and pesticides that are sprayed and used on crops. These harmful chemicals can infiltrate crops and animals and people are at health risk if they eat these crops.

Table 3. Difference between conventional and sustainable agriculture

\begin{tabular}{ll}
\hline Conventional agriculture & Sustainable agriculture \\
\hline Main goal: High yield and high profit & Main goal: Sustainability (Secure Future) \\
\hline Use of agricultural chemicals (fertilizers, pesticides) & No use of agricultural chemicals \\
\hline High environmental damage & Low environmental damage \\
\hline Not eco friendly & Eco friendly \\
\hline Use of GMO crops & No use of GMO (like organic farming) \\
\hline Promotes monoculture (same crop throughout) & Promotes Poly-culture (variety of crops) \\
\hline Reduced biodiversity & High biodiversity \\
\hline High yields & Lower yields (Comparatively) \\
\hline Deteriorates soil health & Makes soil healthy \\
\hline Soil erosion & No soil erosion \\
\hline Requires pesticides form pests and disease management & Crops naturally strong against pests and diseases \\
\hline
\end{tabular}




\begin{tabular}{ll}
\hline Conventional agriculture & Sustainable agriculture \\
\hline High farmer's debts due to high production cost & Low farmer's debts due to low production cost \\
\hline Products contaminated with accepted levels of toxicity & No Contamination and non-toxic \\
\hline Farmers are exposed to chemicals that causes side-effects & Healthy working conditions for farmers \\
\hline Harmful to pollinators & Supports pollinators \\
\hline Better maintenance (Reduced No. of Processes) & Difficult to maintain (Many processes to keep track) \\
\hline Easier to adopt & Relatively difficult to adopt \\
\hline
\end{tabular}

(Source: Soomro 2020).

\section{Sustainable intensification}

Sustainable intensification is a method of increasing production on existing agricultural land while minimizing negative environmental and social consequences. Sustainable intensification entails improving both the production and the environmental management of agricultural land at the same time (RISE Foundation 2014). Sustainable intensification focuses on improving the efficient use of resources for agriculture to produce more food on the same amount of land but with reduced negative environmental or social impacts. The requirement for scaling up sustainable intensification is given in Table 1. The prominence of sustainable intensification is based upon three fundamental assumptions: (i) The world needs to produce significantly more food in the coming decades to feed a growing, increasingly affluent population, (ii) The arable land base cannot be expanded significantly, and (iii) Agricultural production must become more sustainable and resource use efficiency to preserve the natural capital on which agriculture relies. Considered together, these three assumptions imply that agricultural production on existing arable land must intensify to meet higher demand, but in a manner which does not damage the environment (Cook et al 2015).

The fundamentals of Sustainable Intensification (SI) are defined as follows : (i) select and use crop varieties and livestock breeds with a high ratio of productivity to make use of externally and internally derived inputs; (ii) avoid the use of external inputs without need; (iii) harness agroecological processes such as nutrient cycling, biological nitrogen fixation, allelopathy, predation and parasitism;(iv) reduce practice of technologies and other activities which harms human and environmental health; (v) efficient utilization of human capital in which knowledge and adaptation capacity, innovation and social capital belong to resolve common landscape-scale or system-wide problems (such as water, pest or soil management); and (vi) Shrink the consequences of system management on externalities such as clean water, biodiversity, carbon sequestration, greenhouse gas (GHG) emissions and dispersal of pests, pathogens and weeds (The Royal Society 2009).

The areas of sustainable intensification are expressed in terms of efficiency, economy, environment, human condition and social sphere.

Productivity: Increased productivity to increase production per unit of input per unit time (season or year) is the main feature of intensification. Following the SI literature, this area focuses on soil, soil degradation and biodiversity as a critical input threatened by natural habitat loss. Intensification takes place in the economic sphere, using inputs other than land (such as labor, fertilizer, and capital).

Economic: This area addresses issues directly related to the profitability of agricultural activities and the return to production factors. In addition to profitability, this area includes indicators of the productivity of inputs in addition to land: water, nutrients, labor and capital. In addition, indicators that may affect the investment opportunity are included to increase productivity (market share).

Environment: This area focuses on natural resources (eg., soil, water) that support agriculture, environmental services directly affected by agricultural practices (eg., habitat, water holding capacity) and the level of pollution from agriculture (pesticides, greenhouse gases).

The human condition: This field includes individual or household indicators such as nutritional status, food security, and the ability to learn and adapt. These indicators affect a person and do not 
require social interaction or interpersonal relationships. Although these factors depend on social interactions (such as at home or in the community), they are different from factors in the social sphere that directly target interpersonal relationships.

Social: This area focuses on social interactions: gender equality within the household, equal relations between social groups in a community or landscape, the level of collective action, and the ability to resolve conflicts related to agriculture and resource management.

The requirement needs for scaling up sustainable intensification is provided in Table 4.

Table 4. Requirements needed for scaling up sustainable intensification

\begin{tabular}{l|l}
\hline 1 & $\begin{array}{l}\text { Scientific and combination of farmers' input with technologies such that crops and animals are } \\
\text { incorporated with suitable agro-ecological and agronomic managerial activities. }\end{array}$ \\
\hline 2 & $\begin{array}{l}\text { Set up of novel social infrastructure that causes flows of information along with the establishment of } \\
\text { faith among individuals and agencies. }\end{array}$ \\
\hline 3 & $\begin{array}{l}\text { Advancing the knowledge and capacity of farmers through the approach like Farmer Field School } \\
\text { (FFS), farmers trainers, videos and modern Information and Communication Technologies (ICTs). }\end{array}$ \\
\hline 4 & $\begin{array}{l}\text { Collaboration with the private sector to supply goods and services like milk and tea collectors, } \\
\text { manufacturers of implements, seed multipliers and veterinary services as well as strengthen the capacity } \\
\text { of farmers' regarding value addition through their business development. }\end{array}$ \\
\hline 5 & $\begin{array}{l}\text { Special attention on the availability of education, microfinance and agricultural technology to women } \\
\text { and the establishment of unique social capita }\end{array}$ \\
\hline 6 & $\begin{array}{l}\text { Ascertain the availability of microfinance and rural banking to the farmer's groups in terms of both } \\
\text { consumption and production purposes }\end{array}$ \\
\hline 7 & $\begin{array}{l}\text { Ascertain public sector support to increase the required public goods for sustainable intensification of } \\
\text { agriculture in the form of innovative and capable research systems, ease the availability of social } \\
\text { infrastructure, suitable economic incentives (subsidies, price signals), legal status for land ownership } \\
\text { and enhanced access to markets, through development in transport infrastructure }\end{array}$ \\
\hline
\end{tabular}

(Source: Pretty et al 2011)

To achieve sustainable intensification in systems nearing yield potential, it is necessary to enhance yields and environmental performance of top-yielding farmers. However, little research has been conducted in this area (Tseng et al 2020).

\section{Sustainable Agriculture Intensification}

By concept, sustainable agricultural intensification aims to generate more food from the same amount of land while reducing negative environmental impacts and providing social, economic, and environmental benefits (RAU 2021).The characteristics, principles and practices of agricultural sustainable intensification are given in Table 5.

Table 5. Characteristics, principles and practices of sustainable agricultural intensification (Xie et al., 2019).

\begin{tabular}{lll}
\hline \multicolumn{1}{c}{ Sustainable agricultural intensification } & \multicolumn{1}{c}{ Sources } \\
\hline & $\begin{array}{l}\text { 1. Remarkable increase in crop production without any harm to the } \\
\text { natural resources. }\end{array}$ & Pretty 1997. \\
\hline $\begin{array}{l}\text { 2.Check the flow of inputs and outputs of livestock production } \\
\text { systems to improve production with consideration of maintaining } \\
\text { ecological balance and environmental harmony }\end{array}$ & Gibon et al 1999 \\
\cline { 2 - 3 } Characteristics & $\begin{array}{l}\text { 3. Maximize return from the use of land and labor along with } \\
\text { maintain soil nutrient balance. }\end{array}$ & Ruerd and Lee 2000. \\
$\begin{array}{ll}\text { 4. Encourage efficient utilization of natural, social and human assets } \\
\text { and the best available technologies and inputs to lower } \\
\text { environmental damage. }\end{array}$ & Pretty 2008 \\
\hline $\begin{array}{l}\text { 5. Increase crop productivity so that more yield can be obtained from } \\
\text { less land without affecting the environment }\end{array}$ & Pretty and Bharucha \\
\hline
\end{tabular}




\begin{tabular}{|c|c|c|}
\hline & Sustainable agricultural intensification & Sources \\
\hline \multirow{4}{*}{ Principles } & and knowledge to increase production. & Firbank et al 2013 \\
\hline & $\begin{array}{l}\text { 2. Sharpen resource use efficiency, optimize the application of } \\
\text { external inputs, lower the negative impact of food production on the } \\
\text { environment and narrow the yield gap. }\end{array}$ & $\begin{array}{l}\text { Pretty 1997, Matson } \\
1997\end{array}$ \\
\hline & 3. Use of improved crop varieties and livestock breeds. & $\begin{array}{l}\text { Ruerd and Lee 2000, } \\
\text { Pretty } 2008\end{array}$ \\
\hline & 4. Lessen food waste and increase productivity. & Garnett et al 2013 \\
\hline \multirow{6}{*}{ Practices } & $\begin{array}{l}\text { 1. Use of bio fouling and residual plastic film to cover soil, follow } \\
\text { principles of conservation tillage and crop rotation. }\end{array}$ & Wezel et al 2015 \\
\hline & 2. Inclusion of leguminous crops and cover crops in crop rotation. & Tilman et al 2011 \\
\hline & 3. Integrated pest management. & Pretty 1997 \\
\hline & $\begin{array}{l}\text { 4. Sustainability of soil and water conservation, soil health } \\
\text { management. }\end{array}$ & $\begin{array}{l}\text { FAO 2004, Wezel et } \\
\text { al } 2015\end{array}$ \\
\hline & 5. Protection of plant genetic resources and improved varieties. & FAO 2004 \\
\hline & $\begin{array}{l}\text { 6. Insufficient irrigation, additional irrigation, water management, } \\
\text { fertigation. }\end{array}$ & FAO 2004 \\
\hline
\end{tabular}

Measure and technologies required to achieve sustainable agriculture intensification in Himalayan region is given in Figure 2 and Table 6.

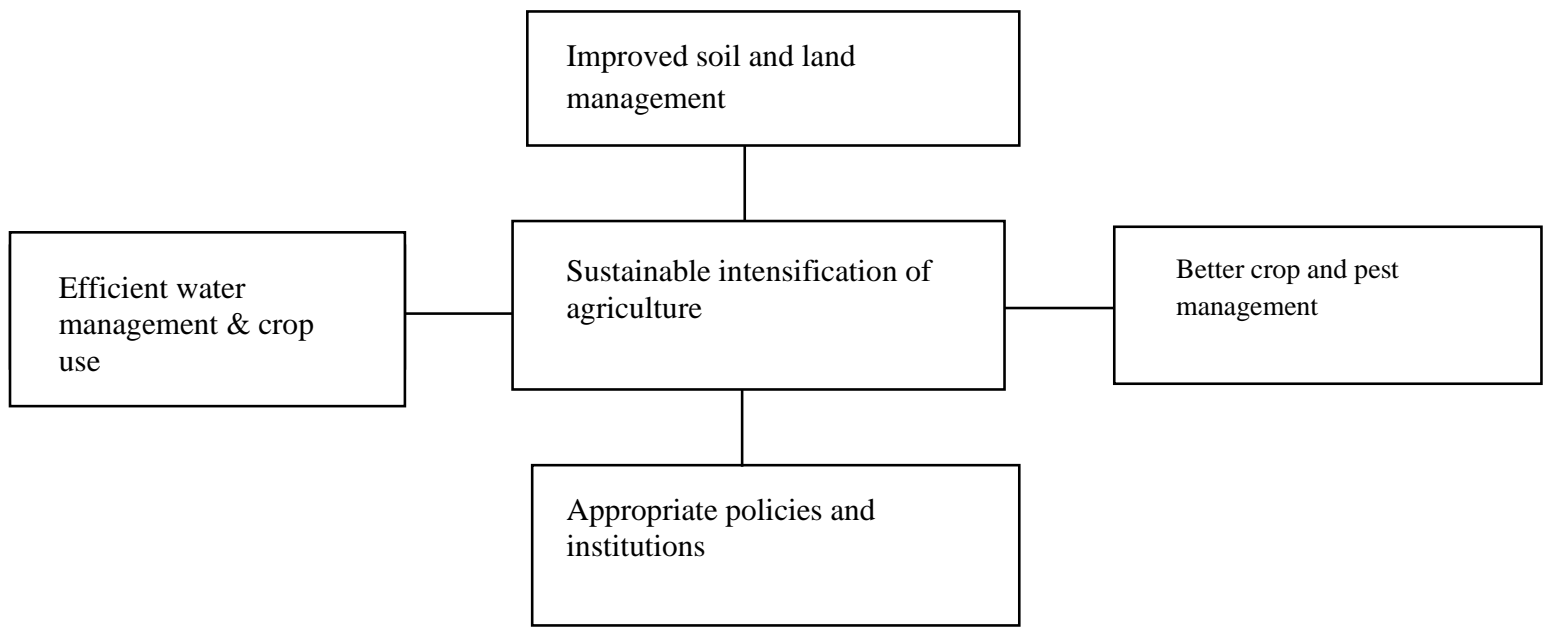

Figure 2. Measure and technologies required to achieve sustainable agriculture intensification in Himalayan region (Bajracharya et al 2014).

Table 6. Measure and technologies required to achieve sustainable agriculture intensification

Resource category

Soil/land resource-

Improved soil management

\section{Measures and technologies}

Improved soil nutrient status and quality by the use of improved composting. through sufficient use of farmyard manure and application of urine.

Upgrading soil organic matter and soil carbon sequestration

Application of biofertilizers and optimization of microbial activities in rhizosphere

Improvement in soil biophysical properties and water retention by the use of biochar and zeolite amendments

Practice of reduced or minimum tillage, crop residue management, and other conservation practices
Water resource management and use efficiency Increase in water use efficiency by the use of microirrigation and timing of application: operate laser level to enhance irrigation/water productivity

Water harvesting and groundwater recharge

Enhanced water retention in soil by the use of zeolites, biochar and mulching Water recycling, wastewater reclamation and reuse, desalinization

Crop/agrobiodiversity resource management
Cultivation of more efficient and risk avoiding crop production systems like agroforestry along with high-value crops, mixed cropping, relay cropping, and intercropping 


\begin{tabular}{ll}
\hline Resource category & Measures and technologies \\
\hline & Improved crop varieties by developing resistance against drought, cold and pest \\
in it and high yielding varieties through genetic modifications \\
Inclusion of forage species, adopting crop rotations and plantation of fruit and \\
fuel wood tree species on private land \\
Pest control by the approach of natural or biological integrated pest \\
management (IPM) \\
\hline Policy and institutional & Sufficient investment in agricultural research \\
initiatives & Provision of technical support to farmers through the means of extension and \\
& outreach services \\
& Institutional support and strengthening of capacity \\
& Effective plans and policies, incentives and stipend to encourage conservation \\
& and sustainable production
\end{tabular}

Source: Bajracharya et al 2014

\section{Sustainable agriculture intensification in Nepal}

In Nepal, there is a food shortage crisis, which is most severe in the mountainous and hill regions, where there is a six-month or longer annual food shortage (Bohle and Adhikari 1998, FAO 2003). The situation could deteriorate unless agricultural productivity and rural economies are improved. Due to improved road connectivity, Nepal's agricultural system is improving and transforming into intensified cropping in peri- and semi-urban areas. Through the process of agricultural intensification in the hills, farmers are becoming increasingly concerned and inclined to grow horticultural and other cash crops instead of cereal crops (Shrestha, 2016). In Nepalese mid hill and semi-urban context, intensification has substituted the traditional practice of farming of two crops in a year into the plantation of three and more crops including vegetables in a year (Dahal et al 2009). Such a transition is possible if intensive farming is adopted throughout the country and paired with suitable technological advances. Due to Nepal's fragile mountainous landscape, this type of intensification must be achieved in an environmentally friendly manner.

Nepalese agriculture faces major challenges such as declining agricultural productivity and rising pressure on soil, water, and forests (Basnyat 1995). A growing human and livestock population exacerbates the problem. It has now become apparent that traditional agricultural systems are no longer sustainable, with both human and livestock population densities exerting a pressure upon the land that is insupportable (Basnyat 1995). The sustainable intensification and agricultural growth provide a way to break the vicious circle of poverty and resource depletion. In the present context of Nepal, the majority of farmers cannot afford the capital expenditure or risk of modifying or intensifying their farming practices. As a result, government policies and practices should promote sustainable intensive farming systems throughout the country from the start, such as through subsidies for improved varieties, fertilizers, agricultural implements, and small agro-industries. Sustainable agricultural growth is critical to ensure food and nutrition security in a country like Nepal (IFPRI 2021). Appropriate crop selection, balanced nutrient and prudent pesticide usage, and implementation of appropriate conservation practices may boost output while minimizing environmental and human health impacts. In Nepal, too, many sustainable agricultural approaches are being adopted. Adoption of zero tillage in wheat and minimum tillage in lentil cultivation, practice of intercropping and mixed cropping, crop rotation, integrated pest management, organic farming, use of drip irrigation technology can be taken as some examples.

\section{Merits and demerits of sustainable agricultural intensification}

Farmers with smaller landholdings and little off-farm revenue have also introduced intensification practices in the watershed because enhanced linkages to urban markets have increased income prospects (Raut et al 2010). The prevailing school of thoughts to grow more food to feed the growing population are: (i) commercialization of agriculture-adopting high input-high output i.e., Western model of the agriculture production system, and (ii) sustainable intensification in agricultureproducing more food from the same area of land to feed humans without damaging the biodiversity and ecosystem services (Shrestha 2016). It is believed that agricultural intensification nurtures the 
existing socio-economic status in Nepal. Studies from Katwal and Sah (1992) showed that agricultural intensification offered important socio-economic benefits to the Nepalese farmers. There is a great contribution of agricultural intensification to thrive employment opportunities in mid-hills of Nepal. It opens new opportunity of employment in the markets of agricultural products, fertilizers and pesticides. Also, it has the merits of food security, increased employment, increased decision making, improved local institutions and local economy of the farmers (Raut et al 2010). Since intensification increases the annual harvests through the cultivation of a greater number of crops in a plot, it thus provides higher production and income opportunities to the farmers. Local farmers with small landholdings are often hired by the farmers with large landholding in order to make them involve in the production practices from cultivation to marketing of the agricultural products (Tiwari et al 2008). Increment in the daily labor wages is incremental to the financially poor and disadvantaged groups. The economic situation of people engaged in agricultural intensification in Nepal's mid-hills has reportedly improved (Katwal and Sah 1992). Agricultural intensification enhanced the quantity of food produced; improvements in food security (Carswell 1997, Katwal and Sah 1992) and farmers can include nutritious food like vegetables as a part of their diet (Tiwari et al 2008).

Agricultural intensification is thought to have certain negative consequences as well. Agricultural intensification has serious implication on environmental degradation. Soil erosion, fertilizer degradation, water quality, and soil organic matter depletion are all issues posed by agricultural intensification (Gardner and Gerrard 2003). Tillage practices in farms have increased as a result of the cultivation of more crops in intensified farming, making soil more vulnerable to erosion and degradation (Tiwari et al 2009). Farm sustainability has been largely challenged in Nepal because intensification practices have relied heavily on the heavy use of chemical fertilizers and pesticides in recent years. Further, unsustainable agriculture practices pose the risks of natural resources over usage in form of inputs which has detrimental environmental effects (Baumol and Oates 1988).

\section{CONCLUSION}

Food security and environment degradation are the two major challenges for sustainable agricultural production in today's world. In order to satisfy the ever-increasing population's food demand, we must increase agricultural production. The adoption of sustainable agricultural intensification increases crop yields with fewer inputs without expanding land use. The sustainable agricultural intensification allows crop production in a sustainable way without adverse effects on environments. Policy and institutional support are essentially needed to move forward and to adopt sustainable agricultural practices worldwide for ensuring food security. The recommendation of this study is that the scientific community should focus their current and future research strategies and efforts on developing better sustainable agricultural practices that are adaptable to changing climatic conditions.

\section{REFERENCES}

Adamczewska-Sowińska K and J Sowiński. 2020. Polyculture management: A crucial system for sustainable agriculture development. In: Soil Health Restoration and Management (pp. 279-319). Springer, Singapore.

Angelsen A and D Kaimowitz. eds. 2001. Agricultural technologies and tropical deforestation (CABI, Wallingford, UK).

Bajracharya RM, DP Sherchan, BM Dahal and N Raut. 2014. Soil Management for Sustainable Agricultural Intensification in the Himalayan Region. Soil Management of Smallholder Agriculture; pp. 143-160.

Baldy CM and CJ Stigter. 1997. Agrometeorology of multiple cropping in warm climates, Translated from the French with an Epilogue to the English edn., INRA, Paris, France; Oxford and IBH Publishing Co., New Delhi, India; Science Publishing Inc., Enfield, U.S.A.; p. 237.

Bashour A, A AI-Ouda, A Kassam, R Bachour, K Jouni, B Hansmann, and C Estephan. 2016. An overview of conservation agriculture in the Dry Mediterranean environments with special focus in Syria and Lebanon. AIMS Agriculture and Food 1(1): 67-84. DOI: https://doi.org/https://doi.org/10.3934/agrfood.2016.1.67

Basnyat BB. 1995. Nepal's agriculture, sustainability and intervention: looking for new directions. Thesis, Wageningen.

Baumol WJ and WE Oates. 1988. The theory of environmental policy (II). Cambridge University Press. DOI: https://doi.org/https://doi.org/10.1017/CBO9781139173513

Biodynamic Association. Biodynamic Principles and Practices. [website]. 2021. Available at: https://www.biodynamics.com/biodynamic-principles-andpractices. 
Bohle H and J Adhikari. 1998. Rural livelihoods at risk: How Nepalese farmers cope with food insecurity. Mountain Research and Development 18(4): 321-332.

Carson B. 1992. The land, the farmer and the future: a soil fertility management strategy for Nepal. ICIMOD Occasional Paper, No. 2.1. ICIMOD, KTM Nepal.

Carswell G. 1997. Agricultural intensification and rural sustainable livelihoods: a "Think Piece" (IDS Working Paper 64). https://opendocs.ids.ac.uk/opendocs/handle/20.500.12413/3368

Chapagain T and GB Gurung. 2010. Effects of Integrated Plant Nutrient Management (IPNM) Practices on the Sustainability of Maize-based Farming Systems in Nepal. Journal of Agricultural Science 2(3): 1-7. DOI: https://doi.org/10.5539/jas.v2n3p26

Clark A. 2015. Cover crops. Cover crops for sustainable crop rotations. Retrieved from https://www.sare.org/resources/cover-crops/

Cook S, L Silici, B Adolph and S Walker. 2015. Sustainable intensification revisited. IIED Issue Paper. IIED, London. $\quad$ Product code: 14651IIED $\quad$ ISBN: 978-1-78431-185-8. https://pubs.iied.org/sites/default/files/pdfs/migrate/14651IIED.pdf Dahal BM, BK Sitaula and RM Bajracharya. 2008. Sustainable agricultural intensification for livelihood and food security in Nepal. Asian Journal of Water, Environment and Pollution 5(2): 1-12.

Dahal BM, I Nyborg, BK Sitaula and RM Bajracharya. 2009. Agricultural intensification: food insecurity to income security in a mid-hill watershed of Nepal. International Journal of Agricultural Sustainability 7(4): 249-260. DOI: https://doi.org/10.3763/ijas.2009.0436

Dang Y. 2019. Special Issue "Conservation Agriculture”. https://www.mdpi.com/ journal/ agriculture/special_issues/conservation_agriculture.

Denton M. 2020. What is sustainable agriculture? PostHarvest. https://www.postharvest.com/blog/what-issustainable-agriculture

Diao X and J Silver. 2016. Urbanization and its impact on Ghana's rural transformation. Unpublished draft. Washington DC: IFPRI.

Donovan M. 2020. What is sustainable intensification? Retrieved from https://www.cimmyt.org/news/what-issustainable-intensification/

Dufour R. 2001. Biointensive Integrated Pest Management (IPM). ATTRA (Appropriate Technology Transfer for Rural Area). Retrieved from https://www.slideshare.net/ElisaMendelsohn/biointensive-integrated-pestmanagement

Eslami S. 2014. Weed management in conservation agriculture systems. Chapter 11: Integrated Weed Management in Horticultural Crops; pp.87-124. DOI: https://doi.org/10.1007/978-1-4939-1019-9_5.

European Commission. Becoming an organic farmer. Organic Farming. [website]. 2021. Available at: https://ec.europa.eu/info/food-farming-fisheries/farming/organic-farming/becoming-organic-farmer_en.

European Parliament and Council. 2018. Regulation (EU) 2018/848 of the European Parliament and of the Council of 30 May 2018 on organic production and labelling of organic products and repealing Council Regulation (EC) No 834/2007. Official Journal of the European Union L 150/1.

Evans M. 2019. Agricultural intensification has fed the world, but are we healthier? https://forestsnews.cifor.org/59674/agricultural-intensification-has-fed-the-world-but-are-wehealthier?fnl=

FAO .2003. Agricultural policies and strategies for poverty alleviation and food security. NEP/99/023: SPPD Report, Kathmandu, FAO.

FAO. 1995. Integrated plant nutrition system. http://www.fao.org/3/v5250e/v5250e.pdf

FAO. 2004. The ethics of sustainable agricultural intensification; Ethics Series; Food and Agriculture Organization of the United Nations: Rome, Italy; pp. 3-5

FAO. 2010. What is conservation? http://www.fao.org/ag/ca.Ia.html.

FAO. 2014. Building a common vision for sustainable food and agriculture. Principles and approaches. Rome.

FAO. 2019. Policy support and governance. Sustainable intensification of crop production. http://www.fao.org/policy-support/policy-themes/sustainable-intensification-agriculture/en/

Farming Base. 2021. What Are the Advantages and Disadvantages of Sustainable Agriculture?. https://farmingbase.com/what-are-the-advantages-and-disadvantages-of-sustainable-agriculture/

Firbank LG, J Elliott and B Drake. 2013.Evidence of sustainable intensification among British farms. Agric. Ecosyst. Environ. 173: 58-65.

Folnovic T. 2021. Polyculture Production System for Sustainable Farming. https://blog.agrivi.com/post/polyculture-production-system-for-sustainable-farming

Gardner RAM and AJ Gerrard. 2003. Runoff and soil erosion on cultivated rainfed terraces in the Middle Hills of Nepal. Applied Geography 12: 23-45. DOI: https://doi.org/10.1016/S0143-6228(02)00069-3

Garnett T, MC Appleby and A Balmford. 2013. Sustainable intensification in agriculture: Premises and Policies. Science 341: $33-34$ 
GC Y. 2011. Status of plant protection activities in Nepal. Capacity Building in Use of the International Phytosanitary Portal (IPP) and APPPC Website for Information Exchange. https://www.ippc.int/static/media/files/publications/1310180880_21b_Nepal2.pdf

Ghosh BN, P Dogra, NK Sharma, R Bhattacharyya and PK Mishra. 2015. Conservation agriculture impact for soil conservation in maize-wheat cropping system in the Indian sub Himalayas. International Soil and Water Conservation Research 3(2): 112-118.

DOI: https://doi.org/https://doi.org/10.1016/j.iswcr.2015.05.001

Gibon A, AR Sibbald and JC Flamant. 1999. Livestock farming systems research in Europe and its potential contribution for managing towards sustainability in livestock farming. Livestock Production Science 61: $121-137$.

Godfray HCJ, JR Beddington and IR Crute. 2010. Food security: The challenge of feeding 9 billion people. Science 327: 812-818

Hobbs PR, K Sayre and R Gupta. 2008. The role of conservation agriculture in sustainable agriculture. Philosophical Transactions of the Royal Society B: Biological Sciences 363(1491): 543-555.

Hossain MI, MJU Sarker and MA Haque. 2015. Status of conservation agriculture based tillage technology for crop production in Bangladesh. Bangladesh Journal of Agricultural Research 40(2): 235-248.

DOI: https://doi.org/https://doi.org/10.3329/bjar.v40i2.24561

IFPRI . 2021. Sustainable agricultural growth in Nepal: Challenges, opportunities and options. https://www.ifpri.org/event/sustainable-agricultural-growth-nepal-challenges-opportunities-and-options

Jha RK. 2008. An assessment of farm-level use of biopesticides in Nepal: A case study based on IPM Farmers' Field Schools of Bhaktapur District. Third Annual Meeting of Plant Protection Society of Nepal.

Jones DL, P Cross, PJA Withers, TH DeLuca, DA Robinson, RS Quilliam, IM Harris, DR Chadwick and G Edwards-Jones. 2013. Nutrient-stripping: the global disparity between food security and soil nutrient stocks. Journal of Applied Ecology 50: 851-862. DOI: https://doi.org/10.1111/1365-2664.12089

Kang BT and FK Akinnifesi. 2000. Agroforestry as alternative land-use production system for the tropics. Natural Resources Forum 24: 137-151.

Kassam A, T Friedrich, F Shaxson, and J Pretty. 2009. The spread of conservation agriculture: justification, spread and uptake. International Journal of Agricultural Sustainability 7: 292-320.

DOI: https://doi.org/10.3763/ijas.2009.0477

Katwal B and L Sah. 1992. Transformation of mountain agriculture: case study. https://agris.fao.org/agrissearch/search.do?recordID=QZ1998000032

Lampeter Permaculture Group. The history of permaculture. [website]. 2006. Available at: http://www.lampeterpermaculture.org/whatis-permaculture/the-history-of-permaculture/.

Leal Filho W, DM Pociovălișteanu, PRB de Brito and IB de Lima eds. 2018. Towards a sustainable bioeconomy: principles, challenges and perspectives. Springer.

Lee $\mathrm{N}$ and $\mathrm{C}$ Thierfelder. 2017. Weed control under conservation agriculture in dryland smallholder farming systems of southern Africa: A review. Agronomy for Sustainable Development 37:48.

DOI: https://doi.org/10.1007/s13593-017-0453-7.

Lu YC, KB Watkins, JR Teasdale and AA Abdul-Baki. 2000. Cover crops in sustainable food production. Food Reviews International 16(2): 121-157.

Matson PA, WJ Parton and AG Power. 1997. Agricultural intensification and ecosystem properties. Science 277: 504-509.

Mollison B. 1988. Permaculture: a designer's manual. Permaculture: a designer's manual.

Naik A. 2017. Integrated nutrient management. https://www.slideshare.net/AshokNaik20/integrated-nutrientmanagement-74367936

Nair PKR. 1993. An introduction to agro-forestry. Kluwer Academic Publishers. Dordrecht/Boston/London

Nin-Pratt A and L McBride. 2014. Agricultural intensification in Ghana: Evaluating the optimist's case for a Green Revolution. Food Policy 48 (1): 153-167.

Noble IR, R Dirzo.1997. Forests as human-dominated ecosystems. Science 277: 522-525.

OrganicNet. 2016. The history of organic farming. [online article]. (30th August 2016). https://www.organicnet.co/en/magazine/the-history-oforganic-farming

Paciello MC. 2015. Understanding food security and agriculture challenges in the Euro-Mediterranean Region. Building Sustainable Agriculture for Food Security in the Euro-Mediterranean Area: Challenges and Policy Options, 23.

Page KL, YP Dang and RC Dalal. 2020. The ability of conservation agriculture to conserve soil organic carbon and the subsequent impact on soil physical, chemical, and biological properties and yield. Frontiers in sustainable food systems. DOI: https://doi.org/10.3389/fsufs.2020.00031 
Pandey RK, TW Crawford Jr and JW Maranville. 2002. Agriculture intensification and ecologically sustainable land use in Niger: a case study of evolution of intensive systems with supplementary irrigation. Journal of Sustainable Agriculture 20(3): 33-55.

Panel M. 2013. Sustainable intensification: A new paradigm for African agriculture. London: Agriculture for impact, 15 Princes Gardens South Kensington Campus Imperial College London SW7 1NA; pp. 1-33.

Parajuli S, J Shrestha and S Ghimire. 2020. Organic farming in Nepal: A viable option for food security and agricultural sustainability. Archives of Agriculture and Environmental Science 5(2): 223-230. DOI: https://doi.org/10.26832/24566632.2020.0502021

Philpott SM. 2013. Biodiversity and pest control services. Encyclopedia of Biodiversity (Second edition). Academic Press, Waltham, MA, second edition; 1:373-384.

Pretty J and ZP Bharucha. 2014. Sustainable intensification in agricultural systems. Annals of botany 114(8): 1571-1596.

Pretty J, C Toulmin and S Williams. 2011. Sustainable intensification in African agriculture. International journal of agricultural sustainability 9(1): 5-24.

Pretty J. 2008. Agricultural sustainability: concepts, principles and evidence. Philosophical Transactions of the Royal Society B: Biological Sciences 363: 447-465. DOI: https://doi.org/10.1098/rstb.2007.2163

Pretty JN. 1997. The Sustainable Intensification of Agriculture. In Natural Resources Forum; Blackwell Publishing Ltd.: Oxford, UK.

Pretty J, TG Benton, ZP Bharucha, LV Dicks, CB Flora, HCJ Godfray and S Wratten. 2018. Global assessment of agricultural system redesign for sustainable intensification. Nature Sustainability 1(8): 441-446.

Pretty J, C Toulmin and S Williams. 2011. Sustainable intensification in African agriculture. Int. J. Agric. Sustain. 9: 5-24. DOI: https://doi.org/10.3763/ijas.2010.0583

Project Drawdown. Conservation agriculture. 2021. [website]. Available at: https://www.drawdown.org/solutions/food/conservation-agriculture

Rahat S. 2015. Intensified agriculture and its merits and demerits. https://www.slideshare.net/BinteAdaam/intensified-agriculture-and-its-merits-and-demerits

RAU (Royal Agricultural University). 2021. Sustainable Agricultural Intensification. Retrieved from https://www.rau.ac.uk/about/organisation/public-information/academic-information/modules/3209sustainable-agricultural

Raut N, BK Sitaula and RM Bajracharya. 2010. Agricultural intensification: linking with livelihood improvement and environmental degradation in Mid-Hills of Nepal. Journal of Agriculture and Environment 11: 83-94. https://doi.org/10.3126/aej.v11i0.3655

Reddy PP. 2012. Biointensive integrated pest management. In: Recent advances in crop protection. Springer, New Delhi; pp. 223-244

Regmi PP. 1987. National Wheat report, 1985/86.

RISE Foundation. 2014: The Sustainable Intensification of European Agriculture. A Review Sponsored by the RISE Foundation. Brussels.

Romeh AA. 2018. Integrated pest management for sustainable agriculture. In: Negm A., Abu-hashim M. (eds) Sustainability of Agricultural Environment in Egypt: Part II. The Handbook of Environmental Chemistry, vol 77. Springer, Cham. DOI: https://doi.org/10.1007/698_2018_267

Roy RN, A Finck, GJ Blair and HLS Tandon. 2006. Plant nutrition for food security. A guide for integrated nutrient management. http://www.fao.org/fileadmin/templates/soilbiodiversity/Downloadable_files/fpnb16.pdf

Ruerd R and D Lee. 2000. Combining Internal and External Inputs for Sustainable Intensification; International Food Policy Research Institute (IFPRI): Washington, DC, USA; pp. 1-2.

Shalaby MY, KH Al-Zahrani, MB Baig, GS Straquadine and F Aldosari. 2011. Threats and challenges to sustainable agriculture and rural development in Egypt: implications for agricultural extension. The Journal of Animal \& Plant Sciences 21(3): 581-588.

Shrestha J, S Subedi, KP Timsina, A Chaudhary, M Kandel and S Tripathi. 2020. Conservation agriculture as an approach towards sustainable crop production: a review. Farming and Management 5(1):7-15.

Shrestha J. 2016. A review on sustainable agricultural intensification in Nepal. International Journal of Business, Social and Scientific Research 4(3): 152-156.

Sitholea NJ, LS Magwazaa, and PL Mafongoya. 2016. Conservation agriculture and its impact on soil quality and maize yield: A South African perspective. Soil and Tillage Research 162: 55-67.

Soomro A. 2020. Conventional farming vs. sustainable agriculture. Retrieved from https://www.environmentbuddy.com/farming/conventional-farming-vs-sustainable-agriculture/

Struik PC and TW Kuyper. 2017. Sustainable intensification in agriculture: the richer shade of green. A review. Agronomy for Sustainable Development 37(5): 1-15.

Sumberg J. 2005. Constraints to the adoption of agricultural innovations: is it time for a re-think? Outlook Agric. 34: 7-10. DOI: https://doi.org/10.5367/0000000053295141 
Szabo Z. 2015. Sustainable intensification of crop production. Retrieved from http://www.eerl.com/Uploads/Sustainable-intensification-of-crop-production-Sept-2015.pdf

The Royal Society. 2009. Reaping the benefits: science and the sustainable intensification of global agriculture. https://royalsociety.org/-/media/Royal_Society_Content/policy/publications/2009/4294967719.pdf

Tilman D, C Balzer and J Hill. 2011. Global food demand and the sustainable intensification of agriculture. Proc. Natl. Acad. Sci. USA; 108: 20260-20264

Tiwari KR, BK Sitaula, RM Bajracharya and T Borresen. 2009. Runoff and soil loss responses to rainfall, land use, terracing and management practices in the Middle Mountains of Nepal. Acta Agriculturae Scandinavica, Section B - Plant Soil Science 59(3): 197-207.

DOI: https://doi.org/10.1080/09064710802006021

Tiwari KR, ILP Nyborg, BK Sitaula and GS Poudel. 2008. Analysis of the sustainability of upland farming systems in the Middle Mountains region of Nepal. International Journal of Agricultural Sustainability 6(4): 289-306. DOI: https://doi.org/10.3763/ijas.2008.0390

Tracy EF. 2015. The promise of biological control for sustainable agriculture: a stakeholder-based analysis. Journal of Science Policy and Governance 5(1):1-13

Tseng MC, A Roel, E Deambrosi, JA Terra, G Zorrilla, S Riccetto and CM Pittelkow. 2020. Towards actionable research frameworks for sustainable intensification in high-yielding rice systems. Scientific reports10(1): $1-13$.

UC Sustainable Agriculture Research and Education Program. 2017. Integrated Pest Management (IPM). What is sustainable agriculture? UC Division of Agriculture and Natural Resources.

Van Doorn A, D Melman, J Westerink, N Polman, T Vogelzang and H Korevaar. 2016. Food for thought: natuurinclusieve landbouw. Wageningen: Wageningen University and Research; p.31

Vedantu. 2021. Sustainable development and organic farming. Retrieved from https://www.vedantu.com/commerce/sustainable-development-and-organic-farming

Wezel A, G Soboksa and S Mcclelland. 2015. The blurred boundaries of ecological, sustainable, and agroecological intensification: A review. Agronomy for Sustainable Development 35: 1283-1295.

$\mathrm{Wu} \mathrm{W}$ and B Ma. 2015. Integrated nutrient management (INM) for sustaining crop productivity and reducing environmental impact: A review. Science of the Total Environment 512: 415-427.

Xie H, Y Huang, Q Chen, Y, Zhang and Q Wu. 2019. Prospects for agricultural sustainable intensification: A review of research. Land 8(11):157. DOI: https://doi.org/10.3390/land8110157

Yadav Y. 1992. Farming-forestry-livestock linkages: a component of mountain farmers' strategies (Nepal). In: NS Jodha, M Banskota, T Partap (Eds.), Sustainable Mountain Agriculture. Perspectives and Issues, Vol. 1. Oxford and IBH Publishing Co. Ltd, New Delhi.

Young A. 1997. The effectiveness of contour hedgerows for soil and water conservation. Agroforestry Forum 8(4): 2-4.

Zhao J, Q Luo, H Deng and Y Yan. 2008. Opportunities and challenges of sustainable agricultural development in China. Philosophical Transactions of the Royal Society B: Biological Sciences 363(1492): 893-904.

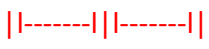

